ER

43,6

Received 28 June 2020 Revised 4 March 2021 Accepted 15 March 2021

\section{High commitment HRM and burnout of frontline food service employees: a moderated mediation model}

\author{
Stephen T.T. Teo, Diep Nguyen, Azadeh Shafaei and Tim Bentley \\ Edith Cowan University, Joondalup, Australia
}

\begin{abstract}
Purpose - Drawing from the Job Demands-Resources (JD-R) framework and Conservation of Resources (COR) theory, the authors' study examines the impact of high commitment HR management (HCHRM) practices and psychological capital (PsyCap) on job autonomy and job demands in predicting burnout in frontline food service employees.

Design/methodology/approach - A moderated mediation model was developed and tested on 257 Australian workers employed in the food service industry. Hypotheses were tested using structural equation modeling.

Findings - There was support for the mediation effect of HCHRM on burnout, via two sequential mediators: job autonomy and job demands. PsyCap was found to buffer (moderation) the effect of job demands on burnout. Frontline employees also perceived HCHRM to be a "negative signal" that was implemented for the good of management.

Research limitations/implications - The authors are aware of the potential of common method variance due to the cross-sectional research design. Future research should adopt a longitudinal research design or collect data from several sources of informants. As the authors did not find support for the optimistic perspective hypothesis, despite its theoretical and empirical relevance under JD-R and COR perspectives, they call for further research exploring the link between HRM, job design and psychological conditions in promoting employee wellbeing.

Practical implications - Burnout is one of the most common and critical health issues faced by frontline food service employees. Food service organizations have to strategize their management practices to reduce employees' experience with burnout by implementing high commitment enhancing HR practices and developing employees' PsyCap.

Originality/value - This study provided a better understanding of how (macro) HCHRM practices as an organizational resource reduce burnout of frontline food service employees via two (micro) mediators: job autonomy and job demands. PsyCap is an important personal resource that lessens burnout, consistent with the COR theory. These findings contribute to the literature on strategic HRM and its relationship to employee wellbeing.
\end{abstract}

Keywords Burnout, Human resource management, Psychological capital

Paper type Research paper

Frontline service workers face a high level of emotional, physical and mental demands in their work (e.g. Hochschild, 1983). Food service companies require their frontline employees to follow formalized and rigid scripts, guidelines and procedures to ensure service excellence (Han et al., 2016). Frontline food service employees may find it challenging to serve difficult or demanding customers as they have to be polite and smile as part of their roles, irrespective of their true emotions (Han et al., 2016). They also experience unsocial and long working hours,

(c) Stephen T.T. Teo, Diep Nguyen, Azadeh Shafaei and Tim Bentley. Published by Emerald Publishing Limited. This article is published under the Creative Commons Attribution (CC BY 4.0) licence. Anyone may reproduce, distribute, translate and create derivative works of this article (for both commercial and non-commercial purposes), subject to full attribution to the original publication and authors. The full terms of this licence may be seen at http://creativecommons.org/licences/by/4.0/legalcode 
excessive job demands, insufficient training, low or unpredictable wages, and job insecurity (Han et al., 2016). These job characteristics result in job stress, burnout, job dissatisfaction and poor retention (Lee and Madera, 2019; Smith, 2018). This situational experience faced by frontline food service employees is the focus of the present study. Burnout refers to a psychological state of continuous exhaustion and disinterest (González-Romá et al., 2006).

We will examine strategic approaches to reducing burnout of Australian frontline employees, as burnout is a critical health-related problem which could lead to high turnover (Han et al., 2016). The relationships between work environmental conditions, job characteristics, employees' behaviors, and burnout could be explained by the Job Demands-Resources (JD-R) framework (Bakker et al., 2005) and the Conservation of Resources (COR) theory (Hobfoll et al., 2018).

In the JD-R framework, JD refers to the psychological, physical, social, and organizational aspects of the job that require employees' skills and effort (Bakker et al., 2005; Bakker and Demerouti, 2017). Hospitality employees experienced JD such as work overload due to the level of fast work pace in their job (Karatepe, 2011). An increase in JD could lead to exhaustion and burnout (Bakker et al., 2005; Bakker and Demerouti, 2017). As an example of resources, JR could foster personal growth, work engagement and employee wellbeing (Bakker and Demerouti, 2017). One example of JR is job autonomy. Job autonomy refers to the degree of independence and discretion in employees' jobs that allow them to autonomously decide what they can do and how they can carry out their work (Hackman and Oldham, 1975). Job autonomy is an important JR for frontline employees as the availability of job autonomy sends a signal to employees that their supervisors have confidence in their skills and abilities in delivering excellent customer service (Karatepe, 2011).

COR theory (Hobfoll et al., 2018) posits that employees have a desire to acquire, sustain, and maintain key resources to prevent a loss of other resources when experiencing high work demands (Hobfoll et al., 2018). According to this theory, employees who face high JD could lose job resources, perceive a threat of losing other resources, or fail to gain other substantial resources. Therefore, they will encounter inadequate resources to buffer JD. When employees experience an on-going and continuous period of high JD and low JR, it could motivate them to acquire and use job-related resources to overcome stressful situations (Bakker et al., 2005; Bakker and Demerouti, 2017). Low JR and high JD can lead to a depletion of energy level, low work identification and lack of perceived efficiency at work, and these situational events start a spiral of resource loss, which signifies the burnout process (Hobfoll et al., 2018). In summary, both JD-R and COR perspectives postulate that adequate resources could lead to positive outcomes and allow employees to invest and attain more resources (Hobfoll et al., 2018).

Another type of resource theorized in this study is HRM system and there is a proliferation of different types of strategic HR practices in the literature (Boon and Kalshoven, 2014; Lepak et al., 2006). The impact of HR practices on employees' wellbeing is also highly contested. While Jensen et al. (2013) argued that HR practices emphasizing high-performance could lead to an increase in role overload and anxiety, Zhong et al. (2016) considered these practices as a potential resource which could lead to job engagement. In this study, we will focus on a highcommitment enhancing HR practices as these practices are a "signal" to employees (Townsend et al., 2012; Zhang et al., 2020) that they are valued and respected by their organization; which in turn, encourages employees to reciprocate with affective commitment (Kroon et al., 2009). HCHRM seeks to "develop committed employees who can be trusted to use their discretion to carry out job tasks in ways that are consistent with organizational goals" (Arthur, 1994, p. 672). A psychological bond between employees and their organizations is then generated (Kroon et al., 2009; Townsend et al., 2012). Therefore, HCHRM will be theorized as an organizational resource.
HCHRM and burnout of food service employees

1343 
ER

43,6

1344

Another type of resource is psychological capital (PsyCap). Luthans and YoussefMorgan (2017) defined PsyCap as a positive cognitive resource with four underlying dimensions, comprising hope (maintaining a goal and, if needed, modify the goal), efficacy (having confidence in achieving success despite challenges), resilience (being able to resist setbacks and find a motivation to continue in the face of failure), and optimism (having positive attitudes about present and future). These four dimensions focus on employees' strength and growth in the workplace (Luthans and Youssef-Morgan, 2017). Consistent with COR theory, PsyCap is consistent with the "notion of "resource caravans," i.e. psychological resources that may travel together and interact synergistically to produce differentiated manifestations over time and across contexts" (Luthans and YoussefMorgan, 2017, p. 343).

This study makes several contributions. First, we will examine how HCHRM play a role in contributing to the psychological and emotional work experience of employees (Peccei and Van De Voorde, 2019) as there is a paucity of HRM-wellbeing research in the hospitality management literature (e.g. Madera et al., 2017). Consistent with the Conservation of Resources (COR) theory (Hobfoll et al., 2018) and the JD-R framework, we will conceptualize HCHRM practices as "organizational resource" and PsyCap as a "personal resource" (Xanthopoulou et al., 2007), that could reduce burnout. Second, we theorize the moderation effect of PsyCap in enhancing the wellbeing of frontline service employees (Hur et al., 2016). This is another contribution to the literature as the buffering effect of PsyCap on burnout remains ambiguous and scant (see Dawkins et al., 2015). Finally, the hypothesized research model will link macro (HCHRM) with micro (job characteristics and PsyCap) level variables.

\section{Literature review, hypotheses development and research framework High commitment HRM and burnout}

It has been widely acknowledged that hospitality service employees experience a high level of stress and burnout (Lee and Madera, 2019; Smith, 2018). One of the most effective approaches to improving employee wellbeing is the implementation of strategic HRM (Peccei and Van De Voorde, 2019). Indeed, some empirical studies found a negative association between strategic HRM and employee burnout. Castanheira and Chambel (2010) found a negative association between high involvement HRM and burnout.

In this study, HCHRM is theorized as bundles of HR practices or system (Lepak et al., 2006) that are designed to enhance high commitment (Boon et al., 2019) in order to maximize employees' wellbeing (Sun and Pan, 2008; Whitener, 2001). HRM system is defined to be a combination of HR practices "that are espoused to be internally consistent and reinforcing to achieve some overarching results" (Lepak et al., 2006, p. 221). Consistent with this literature (Arthur, 1994; Boon et al., 2019; Sun and Pan, 2008), these practices include reasonable and competitive salary, fair treatment, job security, and training. Reasonable and competitive salary could enhance commitment and intention to stay among service employees (Sun and Pan, 2008). Job security fosters employees' responsibility and emotional attachment to the organization and ultimately leads to commitment and retention (Kooij et al., 2010). Practices that demonstrate fair treatment and justice could demonstrate management's emphasis in developing commitment to their employees (Boon and Kalshoven, 2014; Boxall and Macky, 2009). Training can improve employees' abilities and skills that result in job satisfaction and commitment (Sun and Pan, 2008). HCHRM practices focus on performance improvement and produce emotional tie between employees and their organizations (Kroon et al., 2009). Consistent with COR theory, these HR practices could form part of an organizational resources provided to employees to acquire and utilize in the face of high work demands in 
order to enhance their commitment towards their employers (Sun and Pan, 2008). We hypothesize that:

H1. HCHRM practices are negatively related to burnout of frontline food service employees.

Mediation hypotheses: optimistic mediation perspective

We draw from the "optimistic perspective" to hypothesize HCHRM practices as an example of organizational resource. HCHRM practices have a positive association with JR and subsequently lead to a reduction in burnout and an increase in engagement (Boon and Kalshoven, 2014). A recent study by van Veldhoven et al. (2020) supported this notion by arguing that remuneration, training, teamwork, and autonomy, could develop and increase job resources (such as job autonomy, skill use, and skill variety). These resources could increase employee engagement (Kroon et al., 2009). We argue that HCHRM practices reflect a positive signal to employees that they have the necessary resources at their disposal to prevent their loss, which will induce a "gain spiral" and stimulate work engagement (Boon and Kalshoven, 2014). However, this optimistic perspective of COR theory has not received consistent empirical support. For instance, while van de Voorde et al. (2016) found JR to mediate the effect of empowerment HRM on disengagement, Kloutsiniotis and Mihail (2019) did not find JR to mediate the impact of high-performance HRM on burnout. We hypothesize:

$H 2 a$. Job autonomy positively mediates the direct and negative association between HCHRM practices and burnout of frontline food service employees.

\section{Mediation hypotheses: critical mediation perspective}

There is empirical support for the positive relationship between workloads (an example of JD) and the emotional exhaustion of hospitality employees. High job demands can deplete mental, emotional, and physical resources, thus leading to stress, burnout, and strain (Karatepe, 2011). This result is consistent with the "health impairment" process within the JD-R framework (Bakker and Demerouti, 2017) which postulates that high JD such as workloads may exhaust employees' mental and physical resources. This negative experience may lead to energy depletion and emotional exhaustion (Kloutsiniotis and Mihail, 2019).

The health impairment process underpinning the JD-R model can be used to link to the "critical perspective" of HRM (Kroon et al., 2009) that can be used to explain the positive relationship between HCHRM, JD, and burnout. Specifically, the "critical" perspective of HRM suggests a positive association between high-performance HRM and JD (Kloutsiniotis and Mihail, 2019). While high-performance HRM could be used to enhance commitment (Chuang and Liao, 2010), it could also result in work intensification and work overload (examples of JD), and ultimately lead to stress and anxiety (Kroon et al., 2009). Therefore, organizations could use the implementation of high-performance HR practices as a tactic to exploit human capital (Van De Voorde and Beijer, 2015). Others explain this relationship using the labor process theory (Page et al., 2018). While the literature has not paid much attention to this hypothesis, we argue that it is important to explore their relevance. Therefore, we hypothesize:

$H 2 b$. JD positively mediate the negative relationship between HCHRM and burnout.

The JD-R framework postulates that employees are likely to utilize JR to reduce the intensification of JD (Bakker et al., 2005; Bakker and Demerouti, 2017). Having job autonomy also allows employees to manage the pace, flow, and approaches in performing their tasks. Therefore, inadequate level of JR may lead to employee disengagement, whereas an increase in JD may result in burnout (Bakker et al., 2005; Bakker and Demerouti, 2017). There is
HCHRM and burnout of food service employees

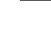


ER

43,6

1346

evidence for the negative association between JR and high JD (Wong et al., 2007; Bakker and Demerouti, 2017). Although the literature suggests that employees can utilize JR to cope with high JD, the findings remain inconclusive (Bakker et al., 2005; Bakker and Demerouti, 2017). For example, although Schaufeli and Bakker (2004) hypothesized a negative association between JR and JD, they did not find any empirical support in two of their samples. We, therefore, hypothesize:

H3. Job autonomy is negatively related to job demands of frontline food service employees.

\section{Psychological capital as a moderator}

PsyCap has been operationalized as a personal resource that positively relates to employees' psychological wellbeing (Grover et al., 2018; Luthans and Youssef-Morgan, 2017). Accordingly, employees tend to protect, accumulate, and utilize their PsyCap to increase their wellbeing. Employees use PsyCap to reduce turnover intentions (Karatepe and Karadas, 2014) or optimize their performance by focusing on positive psychological attributes in periods of high-stress, loss of resources, and high work demands (Min et al., 2015). Consistent with the COR theory, personal resource pays a crucial role in helping employees cope with stress and work demands (Hobfoll et al., 2018). We, thus, hypothesize:

H4. PsyCap has a negative and direct relationship with burnout of frontline food service employees.

PsyCap refers to the feelings of being confident towards challenging tasks, optimistic about current and future failure and success, hopeful and resilient in the face of difficulties, and being able to redirect goal paths to success (Luthans and Youssef-Morgan, 2017). Employees with high PsyCap can carry out various strategies to manage, adjust, and control the way they perform their jobs (Luthans and Youssef-Morgan, 2017). While PsyCap has been theorized as a moderator (Newman et al., 2014), the findings were inconclusive. Yin et al. (2018) found PsyCap to buffer the positive relationship between emotional labor (a form of JD) and emotional exhaustion. Grover et al. (2018) did not find any empirical support in a nursing sample, as an example of frontline service employees. In this study, PsyCap provides the psychological (personal) resource "reservoir" to motivate employees to control and overcome the challenges of service work (Xanthopoulou et al., 2007). Based on the COR theory, we theorize that PsyCap can assist frontline employees to adjust and control demanding and stressful situations with a positive state of mind, thereby reducing burnout.

H5. PsyCap moderates the relationship between JD and burnout such that high PsyCap dampens the positive effect of JD on burnout.

In summary, our study draws upon the JD-R framework and COR theory to test the complex relationships between HCHRM practices, job autonomy, JD, PsyCap, and burnout. The direct, indirect, and moderation effect hypotheses are demonstrated in Figure 1.

\section{Method}

Institutional ethics was obtained before the data collection. Participants' responses were collected using an online panel. PureProfile (a market research company) sent their panel members the participant information letter containing important information about confidentiality, anonymity, and voluntary participation in our study. The letter also included a link directing the participants to the online survey. In this study, we aimed to collect data from frontline food service employees who were older than 18 years old and residing in Australia. We received 257 complete and useable responses (a response rate of 


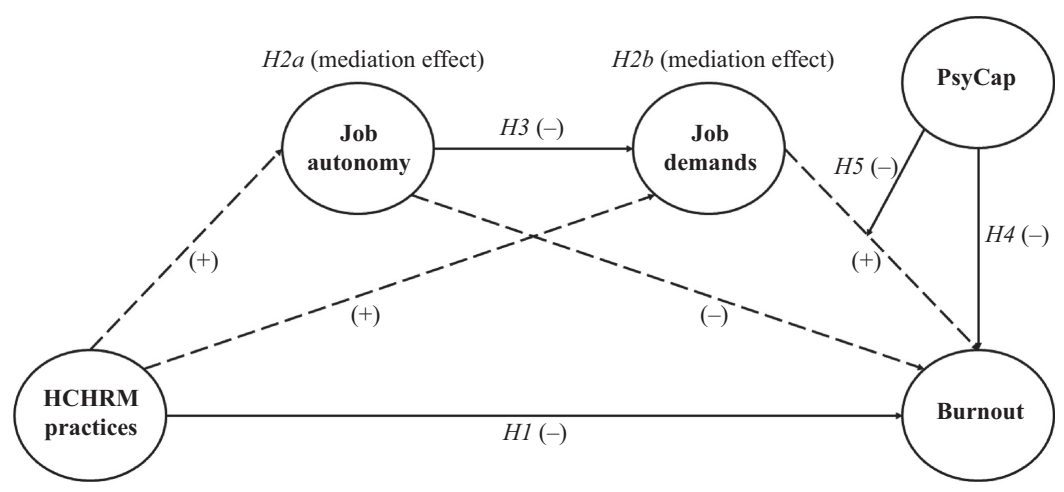

HCHRM and
burnout of food
service
employees

1347

Note(s): Dash lines: mediation effects

$40 \%)$. More than half of the respondents (58.7\%) reported working at least six hours per day. Table 1 presents the demographics of the study participants.

\section{Measures}

We utilized IBM AMOS ver25 to conduct confirmatory factor analysis (CFA) to check the convergent and discriminant validity of the latent variables and perform hypothesis testing. Appendix reports the standardized factor loadings of the items.

HCHRM practices were operationalized as a second-order latent construct comprising four sub-scales adopted from Sun and Pan (2008): salary $(\alpha=0.84)$, justice $(\alpha=0.91)$, job stability $(\alpha=0.81)$, and training $(\alpha=0.94)$. These practices were used to enhance commitment (Kooij et al., 2010; Whitener, 2001). This scale met the minimum requirement for goodness of fit $\left(\chi^{2}\right)$ $\mathrm{df}=2.83, \mathrm{CFI}=0.97, \mathrm{TLI}=0.95, \mathrm{RMSEA}=0.08, \mathrm{SRMR}=0.04$ ). Respondents were asked to indicate their agreement level based on a seven-point Likert scale ranging from " 1 " = strongly disagree to " $7 "=$ strongly agree. Beijer et al. $(2019,10)$ recommended that studies should adopt the descriptive approach in examining HR practices as it closely reflects the actual implementation of HR practices in the workplace. Furthermore, the potential of CMV could be minimized by not using the evaluative approach. Therefore, the HR practices adopted in this study are consistent with this recommendation.

We measured JD using four items from Karasek's (1979) Psychological Demand scale. Three items were used to measure job autonomy (e.g. Karasek, 1979). Respondents were asked to indicate the frequency of their JD and JR on a seven-point Likert scale anchored by " $1 "=$ never to "7" = often. PsyCap was measured with the 12 -item short-form Psychological Capital Questionnaire (Luthans et al., 2007). Respondents were asked to indicate their agreement level on a seven-point Likert scale ranging from " 1 " = strongly disagree to "7" = strongly agree. Three items were removed due to low factor loadings. Consistent with the literature (Karadas and Karatepe, 2019; Luthans et al., 2007), we operationalized this construct as a second-order latent construct with four sub-dimensions: self-efficacy $(\alpha=0.84)$, hope $(\alpha=0.88)$, optimism $(\alpha=0.88)$, and resilience $(\alpha=0.84)$. This multidimensional scale met the minimum requirement for goodness of fit $\left(\chi^{2} / \mathrm{df}=1.85\right.$, CFI $=0.99$, TLI $=0.98$, RMSEA $=0.06$, SRMR $=0.03$ ).

The dependent variable, burnout, was measured with eight items from the Oldenburg Burnout Inventory (Demerouti et al., 2010). This scale was rated on a five-point Likert scale ranging from "1" = strongly agree to " 5 " = strongly agree. Three items were removed as their 
ER
43,6

\begin{tabular}{|c|c|c|}
\hline Demographic background & Categories & $N$ (percent) \\
\hline \multirow[t]{5}{*}{ Firm size } & $0-19$ & $130(50.6 \%)$ \\
\hline & $20-49$ & $60(23.3 \%)$ \\
\hline & $50-99$ & $25(9.7 \%)$ \\
\hline & $100-250$ & $13(5.1 \%)$ \\
\hline & Greater than 250 employees & $29(11.3 \%)$ \\
\hline \multirow[t]{2}{*}{ Gender } & Male & $93(36.2 \%)$ \\
\hline & Female & $164(63.8 \%)$ \\
\hline \multirow[t]{3}{*}{ Marital status } & Single & $104(40.5 \%)$ \\
\hline & Married & $131(51 \%)$ \\
\hline & Divorced/separated & $22(8.5 \%)$ \\
\hline \multirow[t]{6}{*}{ Age } & $18-25$ & $55(21.4 \%)$ \\
\hline & $26-30$ & $52(20.2 \%)$ \\
\hline & $31-40$ & $76(29.6 \%)$ \\
\hline & $41-50$ & $36(14 \%)$ \\
\hline & $51-60$ & $24(9.3 \%)$ \\
\hline & greater than 61 & $14(5.4 \%)$ \\
\hline \multirow{7}{*}{ Education } & Not completed Year 12 & $30(11.7 \%)$ \\
\hline & Completed Year 12 & $63(24.5 \%)$ \\
\hline & Skilled vocational qualifications & $45(17.5 \%)$ \\
\hline & Associate diploma/Adv Cert & $35(13.6 \%)$ \\
\hline & Degree or diploma & $60(23.3 \%)$ \\
\hline & Postgraduate degree or diploma & $16(6.2 \%)$ \\
\hline & Incomplete qualification & $8(3.1 \%)$ \\
\hline \multirow[t]{8}{*}{ Type of establishments } & Hotel/Motel & $24(9.3 \%)$ \\
\hline & Pub/Restaurant (non-fast food) & $58(22.6 \%)$ \\
\hline & Cafe/Coffee shop & $44(17.1 \%)$ \\
\hline & Food court establishment & $13(5.1 \%)$ \\
\hline & Sport/Community Club & $14(5.4 \%)$ \\
\hline & Fast food restaurant & $38(14.8 \%)$ \\
\hline & Takeaway shop & $15(5.8 \%)$ \\
\hline & Other & $51(19.8 \%)$ \\
\hline \multirow[t]{5}{*}{ Working hours per day } & Less than $2 \mathrm{~h}$ a day & $8(3.1 \%)$ \\
\hline & Between 2 and $4 \mathrm{~h}$ a day & $36(14 \%)$ \\
\hline & Between 4 and $6 \mathrm{~h}$ a day & $62(24.1 \%)$ \\
\hline & Between 6 and $8 \mathrm{~h}$ a day & $99(38.5 \%)$ \\
\hline & More than $8 \mathrm{~h}$ a day & $52(20.2 \%)$ \\
\hline \multirow[t]{2}{*}{ Occupational role } & Food preparation and/or production & $91(35.4 \%)$ \\
\hline & Food service (e.g. front of house, serving customers, etc.) & $166(64.6 \%)$ \\
\hline \multirow[t]{5}{*}{ Organization tenure } & Less than 12 months & $70(27.2 \%)$ \\
\hline & $1-2$ years & $66(25.7 \%)$ \\
\hline & $3-5$ years & $74(28.8 \%)$ \\
\hline & $6-10$ years & $27(10.5 \%)$ \\
\hline & more than 10 years & $20(7.8 \%)$ \\
\hline \multirow[t]{4}{*}{ Location } & Inner city & $70(27.2 \%)$ \\
\hline & Suburban & $141(54.9 \%)$ \\
\hline & Regional & $41(16 \%)$ \\
\hline & Remote area & $5(1.9 \%)$ \\
\hline \multirow{5}{*}{ Employment type } & Temporary & $7(2.7 \%)$ \\
\hline & Casual part-time & $87(33.9 \%)$ \\
\hline & Casual full-time & $29(11.3 \%)$ \\
\hline & Permanent part-time & $53(20.6)$ \\
\hline & Permanent full-time & $81(31.5 \%)$ \\
\hline
\end{tabular}

Table 1.

Demographic characteristics of 257 respondents in this study

\section{8}


factor loadings were below 0.60 (Hair et al., 2010). The CFA showed that a single-factor scale $\left(\chi^{2} / \mathrm{df}=1.05, \mathrm{CFI}=0.99, \mathrm{TLI}=0.99, \mathrm{RMSEA}=0.01, \mathrm{SRMR}=0.02\right)$.

Consistent with previous research, we incorporated several control variables (e.g. Karatepe, 2011; Teo et al., 2019). These were the type of hospitality establishments, age, gender, firm size, employment status, number of working hours, and tenure. Prior to undertaking the model testing, we ran an ANOVA test to check if establishment types and firm size impacted the adoption of HCHRM practices. We also conducted an ANOVA for the four underlying dimensions of HCHRM latent factor for between group differences for establishment types and size. The analyses showed that there was no significant statistical difference in the means of these variables. These findings suggest that respondents from different establishment types and size did not report any difference in how they experienced these HCHRM practices.

\section{Measurement model estimation}

We first examined the item loadings of the latent constructs. As shown in Appendix, the standardized factor loadings of the scale items were greater than 0.60 and statistically significant at $p<0.001$ (Hair et al., 2010). To ensure indicators of each construct measure what they are supposed to measure, we tested both convergent and discriminant validity of the constructs. As shown in Table 3, the correlation values among latent variables ranged from 0.09 to 0.55 , the average variance estimates (AVE) of the latent constructs were above 0.50, and the composite reliabilities (CR) of each scale was greater than 0.70 . The hypothesized fivefactor model had the best fit $\left(\lambda^{2}=724.61, \mathrm{df}=360, \mathrm{CFI}=0.92\right.$, TLI $=0.91$, RMSEA $=0.06$, $\mathrm{SRMR}=0.07$, Byrne, 2016). The findings indicated that each latent variable had convergent validity.

Next, we performed several checks for the discriminant validity of the latent constructs. Specifically, we conducted a Chi-square difference test to compare the fit indices of the hypothesized model with alternate models (see Table 2). The results of the analysis indicated that the hypothesized model had the best fit. Additionally, the square root of the AVE value for each construct (see Table 3) was much larger than its correlation with any other construct (Fornell and Larcker, 1981). Furthermore, the value of Maximum Shared Variance (MSV) for each construct was smaller than its relative AVE value (Hair et al., 2010). In summary, these
HCHRM and burnout of food service employees

1349

\begin{tabular}{|c|c|c|c|c|c|c|c|c|}
\hline Model & $\chi^{2}$ & df & CFI & TLI & RMSEA & SRMR & $\begin{array}{l}\Delta \chi^{2} \text { from } 5 \text { - } \\
\text { factor model }\end{array}$ & \\
\hline $\begin{array}{l}\text { 5-factor model (HCHRM, Job } \\
\text { demands, Job autonomy, PsyCap, }\end{array}$ & 724.61 & 360 & 0.921 & 0.911 & 0.063 & 0.07 & $\begin{array}{l}\text { Preferred } \\
\text { model }\end{array}$ & \\
\hline $\begin{array}{l}\text { Burnout) } \\
\text { 4-factor model (HCHRM, Job } \\
\text { demands, Job autonomy + PsyCap, } \\
\text { Burnout) }\end{array}$ & 1245.79 & 367 & 0.810 & 0.790 & 0.097 & 0.09 & $\begin{array}{l}\Delta \chi^{2} \\
(7)=521.18 \\
p<0.001\end{array}$ & \\
\hline $\begin{array}{l}\text { 3-factor model (HCHRM, Job } \\
\text { demands + Job } \\
\text { autonomy + PsyCap, Burnout) }\end{array}$ & 1702.09 & 370 & 0.713 & 0.685 & 0.119 & 0.11 & $\begin{array}{l}\Delta \chi^{2} \\
(10)=977.48 \\
p<0.001\end{array}$ & \\
\hline $\begin{array}{l}\text { 2-factor model (HCHRM, Job } \\
\text { demands + Job }\end{array}$ & 2143.91 & 372 & 0.618 & 0.583 & 0.136 & 0.13 & $\Delta \chi^{2}$ & \\
\hline $\begin{array}{l}\text { autonomy + PsyCap }+ \text { Burnout) } \\
\text { Single-factor model }\end{array}$ & 3170.33 & 376 & 0.397 & 0.349 & 0.170 & 0.16 & $\begin{array}{l}p<0.001 \\
\Delta \chi^{2} \\
(16)=2445.72 \\
p<0.001\end{array}$ & $\begin{array}{r}\text { Table } 2 . \\
\text { Results of Chi-squares } \\
\text { difference test }\end{array}$ \\
\hline
\end{tabular}




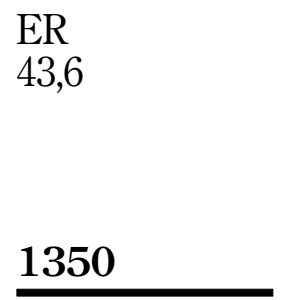

Table 3.

Descriptive statistics and correlations between latent variables

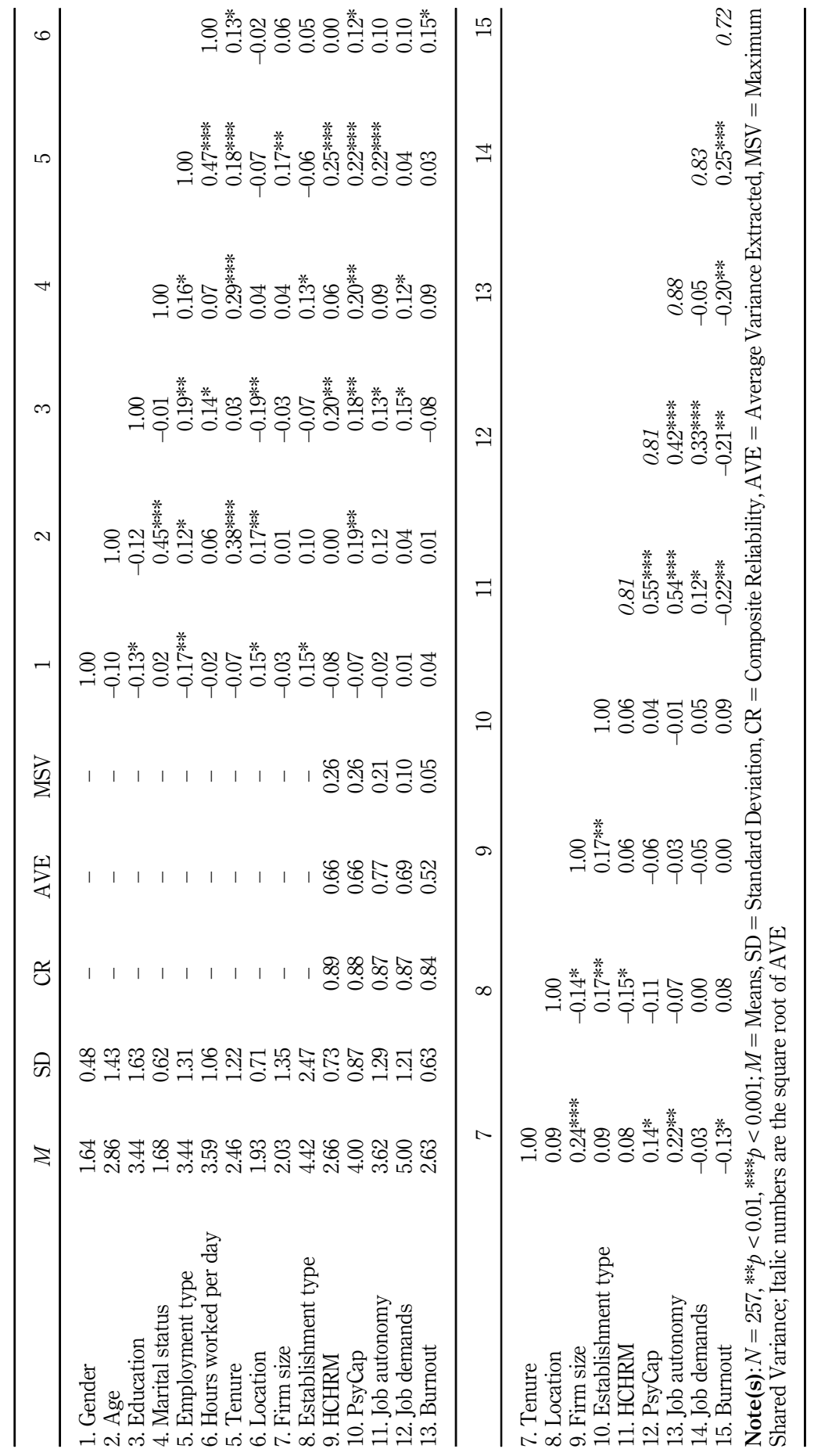


statistical analyses provided assurance that the five latent constructs had convergent and discriminant validity.

\section{Common method variance (CMV)}

We followed Podsakoff et al. (2012) by performing various remedies to prevent the potential of $\mathrm{CMV}$ as the data were cross-sectional and collected at one point in time. First, we emphasized the voluntary nature of participation, confidentiality and anonymity in the study in the information letter. Second, we adopted validated scales to operationalize the latent constructs and arranged them in random order with different endpoints. These remedies helped to minimize the social desirability of the participants in answering the survey.

Additionally, we performed some other statistical checks in the data for the potential of CMV: Harman's single-factor test and common latent factor using the specific bias test (following Gaskin and Lim, 2017). These techniques are commonly adopted by hospitality scholars (Min et al., 2015). First, we entered all the items in an unrotated, principal components extraction factor analysis. The results revealed seven factors with an eigenvalue greater than 1 , indicating that no single factor accounted for most of the variance. Second, the CFA of the five-factor model demonstrated a good fit to the data $\left(\lambda^{2}=724.61\right.$, $\mathrm{df}=360$, CFI $=0.92$, TLI $=0.91$, RMSEA $=0.06$, SRMR $=0.07$ ). Likewise, the CFA of the six-factor model including a common latent factor showed a good fit to the data $\left(\lambda^{2}=555.03\right.$, $\mathrm{df}=331$, $\mathrm{CFI}=0.95$, TLI $=0.94$, RMSEA $=0.05$, SRMR $=0.05$ ). We, therefore, undertook a Chi-square different test between unconstrained and zero constrained models (Gaskin and Lim, 2017). The result $(\phi=1.00)$ indicated that no specific response bias influenced our proposed fivefactor model. Finally, the incorporation of moderation and mediation effects provided a further check for CMV (Podsakoff et al., 2012). In summary, these findings suggested that CMV was not a major issue in the present study.

\section{Analysis and results}

Descriptive statistics and inter-correlations are reported in Table 3. Frontline food service employees reported a below-average level of implementation of HCHRM $(M=3.34$, $\mathrm{SD}=0.90)$. Job demands was above average $(M=5.02, \mathrm{SD}=1.21)$ while job autonomy was below average $(M=2.83, \mathrm{SD}=1.24)$. PsyCap was at the mid-point of the 7 -point scale $(M=4.21, \mathrm{SD}=0.90)$. Burnout was at the mid-point of the 5 -point scale $(M=2.50, \mathrm{SD}=0.63)$. Several demographic variables were statistically associated with the variables in the hypothesized model. These were age, education, marital status, employment type, average hours worked per day, tenure, and location of the establishment. They were retained for further testing in the structural equations modelling.

Path analysis and mediation effect testing were undertaken on AMOS based on 10,000 bootstrap samples. As indicated by the results (see Figure 2), the $R^{2}$ value for burnout was 0.23 (goodness of fit indices: $\chi^{2} / \mathrm{df}=1.119$, CFI $=0.99$, TLI $=0.99$, RMSEA $=0.05$, SRMR $=0.05$ ). Only two control variables had significant positive association with the variables in the model. These were organizational tenure and job autonomy $(\beta=0.156$, $p<0.001)$ and age and burnout $(\beta=0.163, p<0.01)$. There was no statistical association between HCHRM practices and burnout; thus Hypothesis 1 was not supported. Hypothesis 2a was not supported as job autonomy did not mediate the association between HCHRM and burnout, despite a positive association between HCHRM and job autonomy $(\beta=0.529$, $p<0.001$ ). There was a significant, positive relationship between HCHRM practices and JD $(\beta=0.216, p<0.01)$ and a positive direct association between JD and burnout $\beta=0.321$, $p<0.001$ ). Based on these direct relationships, JD was found to be a full mediation for HCHRM practices and burnout (effect $=0.060, \mathrm{SE}=0.027,95 \% \mathrm{CI}[0.023,0.115], p<0.01$ ), supporting
HCHRM and burnout of food service employees

1351 
ER
43,6

1352

Figure 2.

Direct relationships from path analyses
Figure 3.

Moderation effect of PsyCap on the relationship between job demands and burnout

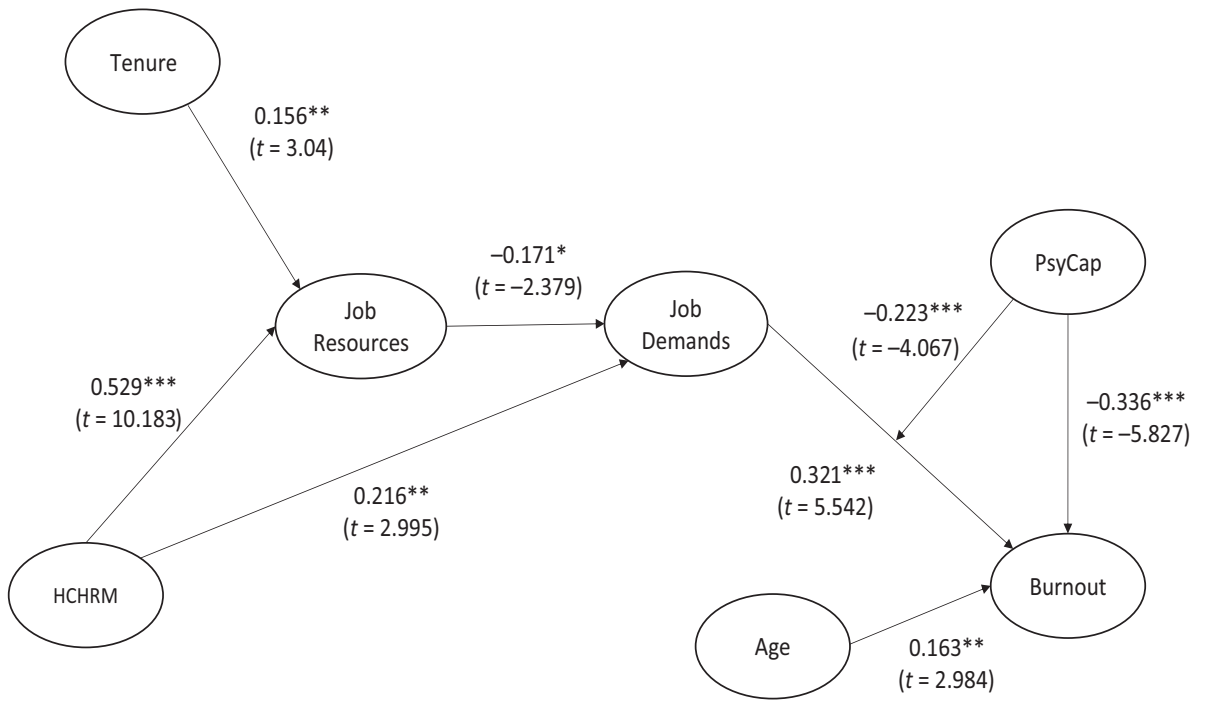

Note(s): $N=257,{ }^{*} p<0.05,{ }^{* *} p<0.01,{ }^{* * *} p<0.001$

Hypothesis $2 \mathrm{~b}$. As we expected, the negative relationship between job autonomy and JD was statistically significant $(\beta=-0.171, p<0.01)$, supporting Hypothesis 3 . Furthermore, we found a negative association between PsyCap and burnout $(\beta=-0.336, p<0.001)$, supporting Hypothesis 4. Drawing from these findings, we conducted a post-hoc analysis to test for a sequential mediation effect of HCHRM $\rightarrow$ job autonomy $\rightarrow$ job demands $\rightarrow$ burnout. A 95\% confidence interval based on 10,000 bootstrap samples did not include zero, showing that job autonomy and JD sequentially mediated the HCHRM practices-burnout association $(b=-0.025$, SE $=0.014,95 \% \mathrm{CI}[-0.053,-0.007], p<0.05)$.

To test for the moderation effect, we mean-centered PsyCap and JD prior to computing an interaction term. The interaction term was then incorporated into the path model for the moderation analysis. There was support for Hypothesis 5 as the moderation effect of PsyCap on JD $\rightarrow$ burnout was significant $(\beta=-0.223, p<0.001)$. Based on this finding, we plotted the interaction effect in Figure 3. The moderation plot shows that irrespective of the levels of JD, employees with higher level of PsyCap were able to control and manage their workload demands, resulting in a lower perceived level of burnout.

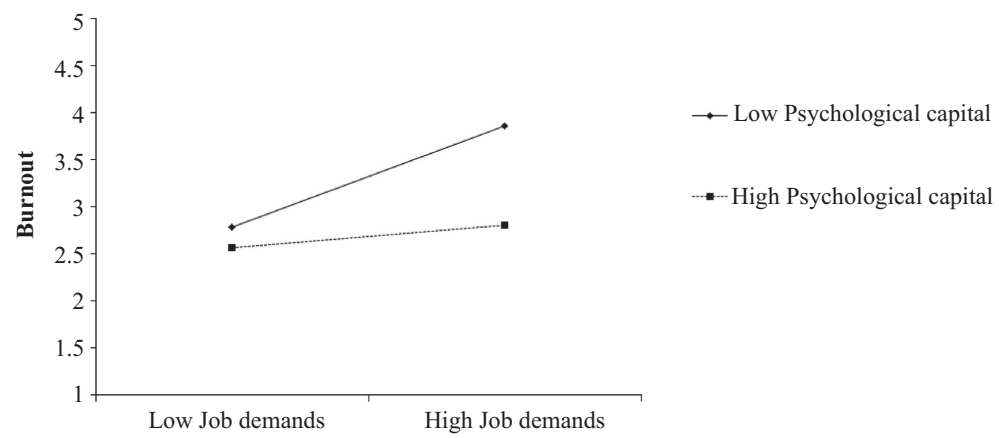




\section{Discussion and implications}

Frontline food service employees face a high level of emotional, physical, and mental demands in their work (Hochschild, 1983; Lee and Madeira, 2019), increasing their vulnerability to burnout and the attendant problems of reduced performance, ill-health, job dissatisfaction, and leave intentions. This study responds to the need to better understand how strategic HR systems, as a form of organizational resource, influence the wellbeing of food service sector employees. Specifically, the study aimed to investigate the impacts of HCHRM practices on job characteristics (i.e., job autonomy and JD) and burnout experienced by frontline food service employees in Australia. We also examined the moderation effect of PsyCap in buffering the positive influence of JD on burnout. Drawing from the JD-R framework and the COR theory, the research findings in our study provide a better understanding of the mechanism linking the implementation of (macro) $\mathrm{HCHRM}$ practices to two (micro) perceptual mediators - job autonomy and JD - in reducing burnout in a hospitality context. Based on these findings, there are two mechanisms by which HCHRM practices could influence burnout. The first mechanism shows that HCHRM practices could impact burnout through a sequential mediation mechanism consisting of both job autonomy and JD. The second approach is a full mediation effect of JD on the relationship between HCHRM practices and burnout. These findings contributed to the literature (Guest, 2017). Finally, this study shows that PsyCap is a personal resource that reduces burnout, consistent with the COR theory.

There was no support for the "optimistic perspective" (Boon and Kalshoven, 2014) where job autonomy mediates the relationship between HCHRM practices and burnout. However, we found that job autonomy is a core resource for frontline food service employees to control and cope with stressful situations. The relationships between HCHRM practices, job autonomy, and JD highlight a compelling reason for the implementation of HCHRM practices in food service organizations as it increases employees' perceptions of acquiring adequate job autonomy to minimize JD (Han et al., 2016; Peccei and Van De Voorde, 2019). More importantly, we found empirical evidence for the "health impairment" hypothesis (Kloutsiniotis and Mihail, 2019; Kroon et al., 2009) that corroborates the literature (Han et al., 2016; Van De Voorde and Beijer, 2015). Specifically, the positive associations from HCHRM practices $\rightarrow \mathrm{JD} \rightarrow$ burnout (Hypothesis $2 \mathrm{~b}$ ) are consistent with the competing mediation hypothesis (Kloutsiniotis and Mihail, 2019; Kroon et al., 2009), indicating that frontline food service employees perceive HCHRM as a "negative signal" which was implemented for the good of management (Van De Voorde and Beijer, 2015). Taken together, the post-hoc analysis which showed the indirect (full mediation) of HCHRM practices $\rightarrow$ burnout was via two serial mediators, job autonomy and JD.

In line with the original conceptualization of PsyCap by Luthans and colleagues (Luthans and Youssef-Morgan, 2017), PsyCap is a consolidated construct of four dimensions: hope, optimism, resilience, and self-efficacy. The final contribution of our study is the way we operationalized PsyCap as a personal resource (Grover et al., 2018; Xanthopoulou et al., 2007) to buffer against the positive effect of JD on burnout (Yin et al., 2018). First, the negative association between PsyCap and burnout in this study supports the argument that PsyCap focuses on employees' strengths and growth in the workplace (Luthans and Youssef-Morgan, 2017). Second, our study showed that PsyCap is important to help food service employees elevate their positive outcomes when experiencing JD. Lastly, the significant moderation effect of PsyCap indicated that PsyCap enables employees to offset their loss of resources and achieve better work outcomes (Hobfoll et al., 2018). Specifically, Figure 3 shows that the positive relationship between JD and burnout becomes weaker for those who have high PsyCap. This result means that when food service employees possess a high level of PsyCap, they would be better able to control, manage, and overcome the challenges of the demanding and stressful workplace situations, thereby reducing the risk of burnout.
HCHRM and burnout of food service employees

1353 
ER

43,6

1354

\section{Managerial implications}

Industry evidence highlights burnout as a key health-related issue in hospitality organizations, as food service employees often experience high workloads and work-pace, and much emotional effort (Salazar, 2018). The costs of burnout go beyond a reduction of productivity, requiring food service organizations to invest in implementing strategic HR practices to help employees gain confidence in doing their jobs. One strategy is to implement HCHRM practices to make employees feel more engaged and committed. Specifically, we suggest that HR managers could consider the provision of training programs to develop food service employees' problem-solving skills to cope with the customer-related job demands (Choo and Aizzat, 2016).

Additionally, the job design of food service roles could incorporate a greater level of job autonomy. As has been shown in the hospitality management literature, service employees do have some degree of autonomy in performing their job roles (Cai et al., 2019). Job autonomy refers to the opportunity for employees to do their jobs with independence and freedom (e.g. Hackman and Oldham, 1976). Choo and Aizzat (2016) noted that service employees must be able to decide promptly and efficiently, in order to satisfy customers' demands. Similar to Volmer et al. (2012), we concur that service employees do have a degree of autonomy as they have a degree of "liberty and freedom" in determining the pace, order, and approaches in servicing customers in food service establishments. Wang et al. (2017) noted that in deciding how to provide a delightful service experience, management could provide service employees a level of autonomy in order for them to prioritize how to deliver the level of service. Others such as Qiu et al. (2020) noted that autonomy could enhance hospitality experience as frontline service employees are able to exercise how to build rapport with customers. Goussinsky (2015) noted that job autonomy moderated how service employees experienced frequent exposure to customer aggression.

In the practitioner literature, it has also been acknowledged that restaurant workers are often students or people with families who might have other responsibilities in their personal lives that require them to schedule around their work shifts (source: https://www.netwaiter. net/articles/5-easy-ways-encourage-restaurant-staff-independence/). Therefore, the literature has shown that autonomy is found in the service management literature and is beneficial for employees working in food service context. Furthermore, food service organizations need to provide fair wages and reasonable workloads and working hours to improve employees' wellbeing. Lastly, top management and direct supervisors have an important role in providing employees with training, constructive feedback, and career development opportunities. These practices are consistent with the underpinning of high commitment focus of HRM (Kooij et al., 2010; Sun and Pan, 2008; Whitener, 2001) and could be implemented to minimize burnout through JR.

Cafes and other smaller food service establishments are changing their business model in the context of COVID-19 pandemic (see Baum et al., 2020, p. 2,820) by "innovating their website and mobile ordering systems. And a number of quick service and fast casual chains are selling groceries and some of their ingredients as groceries, keeping revenues flowing, employment opportunities and community goodwill where grocery stores have been inundated." These changes would require small business food establishments to invest in training and further develop their workers so that they could operate under the new business model. This would ultimately become a talent management strategy in an industry where there is high turnover (see discussion by Golubovskaya et al., 2019).

The HCHRM scale considered training and progression as two HR practices being used to demonstrate high commitment. Development opportunity in this study refer to the provision of training opportunity. This training could include safety and health, food hygiene, customer service, etc. These training activities are commonly offered to food establishments of all sizes, especially those establishments with small size and not have access to these training 
resources such as those offered by industry body such as Restaurant and Catering Australia. Training is an important human resource strategy in food establishments, especially in the era of COVID-19 pandemic in Australia, such as the training programs offered by The Australian Hotel Associations in Western Australia (https:/www.mediastatements.wa.gov. au/Pages/McGowan/2020/04/COVID-19-hygiene-training-sets-course-for-hospitalityrecovery.aspx).

We also suggest the involvement of line managers and direct supervisors in implementing $\mathrm{HR}$ practices as they are the signals that food service organizations care for their employees (Townsend et al., 2012; Zhang et al., 2020). If employees perceive the signals incorrectly, this is likely to impede the potential benefit of a strategic HRM approach. If they were not implemented properly, HCHRM practices could create an unnecessary "negative" signal, increasing the likelihood of JD and burnout. Finally, we recommend a PsyCap intervention involving training and development programs. Food service organizations can use such initiatives to develop and enhance the four psychological attributes of employees: hope, selfefficacy, resilience, and optimism. Based on the suggestion from Karatepe and Karadas (2014), we argue that training programs could focus on promoting personal growth and career development as these are key factors in decreasing employees' burnout. To conclude, a PsyCap intervention is fundamental in assisting food service employees to overcome stressful circumstances at the workplace.

\section{Limitations and future studies}

We are aware of the potential limitation of CMV caused by the cross-sectional research design. However, several checks for CMV were performed, with results indicating CMV was not a threat in this study. Regardless, we recommend a longitudinal research design or data collection from several sources of informants (Beijer et al., 2019). As we did not find support for the optimistic perspective hypothesis, despite its theoretical and empirical relevance under COR and JD-R perspectives (Kloutsiniotis and Mihail, 2019), we call for further research exploring the link between HRM, job characteristics and design, and psychological conditions in promoting employee wellbeing (Guest, 2017). There is a possibility that frontline service employees have to juggle work and life, which may influence employees' burnout. Future studies could examine the work-family boundary conditions (Mansour and Tremblay, 2018) in order to better understand if burnout was predicted by job characteristics such as JD and JR, in addition to work family conflict.

Future studies could also investigate the generalizability of the findings in different national (Van Veldhof et al., 2020) or job settings (Kilroy et al., 2016). Due to the inconclusive finding for the positive perspective to our HRM-wellbeing hypothesis, future research should continue to explore the conditions under which HRM systems affect food service employees' wellbeing, especially in line with the recommendations in the hospitality HRM literature (Madera et al., 2017).

\section{Conclusion}

Drawing from JD-R and COR perspectives, we found empirical evidence for the importance of HCHRM practices in providing foodservice employees adequate job autonomy to deal with job demands and ultimately reduce burnout. Additionally, we found PsyCap to be an important personal resource in buffering against the positive impact of JD on the burnout of foodservice employees. Based on these findings, we discussed several theoretical implications and considered managerial implications. To conclude, the current study contributes to the literature on how foodservice organizations can use HCHRM practices to alleviate employee burnout. 
ER

43,6

\section{References}

Arthur, J.B. (1994), "Effects of human resource systems on manufacturing performance and turnover", Academy of Management Journal, Vol. 37, pp. 670-687.

Bakker, A.B. and Demerouti, E. (2017), "Job demands-resources theory: taking stock and looking forward", Journal of Occupational Health Psychology, Vol. 22, pp. 273-285.

Bakker, A.B., Demerouti, E. and Euwema, M.C. (2005), "Job resources buffer the impact of job demands on burnout”, Journal of Occupational Health Psychology, Vol. 10, pp. 170-180.

Baum, T., Mooney, S.K.K., Robinson, R.N.S. and Solnet, D. (2020), "COVID-19's impact on the hospitality workforce - new crisis or amplification of the norm?", International Journal of Contemporary Hospitality Management, Vol. 32 No. 9, pp. 2813-2829.

Beijer, S., Peccei, R., Van Veldhoven, M. and Paauwe, J. (2019), "The turn to employees in the measurement of human resource practices: a critical review and proposed way forward", Human Resource Management Journal. doi: 10.1111/1748-8583.12229.

Boon, C. and Kalshoven, K. (2014), "How high-commitment HRM relates to engagement and commitment: the moderating role of task proficiency", Human Resource Management, Vol. 53, pp. $403-420$.

Boon, C., Den Hartog, D.N. and Lepak, D.P. (2019), "A systematic review of human resource management systems and their measurement", Journal of Management, Vol. 45, pp. 2498-2537.

Boxall, P. and Macky, K. (2009), "Research and theory on high-performance work systems: progressing the high-involvement stream”, Human Resource Management Journal, Vol. 19 No. 1, pp. 2-23.

Byrne, B.M. (2016), Structural Equation Modelling with AMOS: Basic Concepts, Applications, and Programming, 3rd ed., Routledge, New York.

Cai, Z., Huo, Y., Lan, J., Chen, Z. and Lam, W. (2019), "When do frontline hospitality employees take charge? Prosocial motivation, taking charge, and job performance: the moderating role of job autonomy”, Cornell Hospitality Quarterly, Vol. 60 No. 3, pp. 237-248.

Castanheira, F. and Chambel, M.J. (2010), "Reducing burnout in call centers through HR practices", Human Resource Management, Vol. 49, pp. 1047-1065.

Choo, L.S. and Aizzat, M.N. (2016), "Supervisor support and work engagement of hotel employees in Malaysia Is it different for men and women?", Gender in Management: An International Journal, Vol. 31 No. 1, pp. 2-18.

Chuang, C.H. and Liao, H.U.I. (2010), "Strategic human resource management in service context: taking care of business by taking care of employees and customers", Personnel Psychology, Vol. 63 No. 1, pp. 153-196.

Dawkins, S., Martin, A., Scott, J. and Sanderson, K. (2015), "Advancing conceptualization and measurement of psychological capital as a collective construct”, Human Relations, Vol. 68, pp. 925-949.

Demerouti, E., Mostert, K. and Bakker, A.B. (2010), "Burnout and work engagement: a thorough investigation of the independency of both constructs", Journal of Occupational Health Psychology, Vol. 15, pp. 209-222.

Fornell, C. and Larcker, D.F. (1981), "Evaluating structural equation models with unobservable variables and measurement error", Journal of Marketing Research, Vol. 18, pp. 39-50.

Gaskin, J. and Lim, J. (2017), “CFA tool”, AMOS Plugin, Gaskination's StatWiki, available at: http:// statwiki.kolobkreations.com/index.php?title=Plugins (assessed 6 January 2020).

Golubovskaya, M., Solnet, D. and Robinson, R.N.S. (2019), "Recalibrating talent management for hospitality: a youth development perspective", International Journal of Contemporary Hospitality Management, Vol. 31 No. 10, pp. 4105-4125.

González-Romá, V., Schaufeli, W.B., Bakker, A.B. and Lloret, S. (2006), "Burnout and work engagement: independent factors or opposite poles?”, Journal of Vocational Behavior, Vol. 68, pp. 165-174. 
Goussinsky, R. (2015), "Customer aggression, felt anger and emotional deviance: the moderating role of job autonomy", International Journal of Quality and Service Sciences, Vol. 7 No. 1, pp. 50-71.

Grover, S.L., Teo, S.T.T., Pick, D., Roche, M. and Newton, C.J. (2018), "Psychological capital as a personal resource in the JD-R model", Personnel Review, Vol. 47, pp. 968-984.

Guest, D.E. (2017), "Human resource management and employee well-being: towards a new analytic framework", Human Resource Management Journal, Vol. 27, pp. 22-38.

Hackman, J.R. and Oldham, G.R. (1975), "Development of the job diagnostic survey", Journal of Applied Psychology, Vol. 60, pp. 159-170.

Hackman, J.R. and Oldham, G.R. (1976), "Motivation through the design of work: test of a theory", Organizational Behavior and Human Performance, Vol. 16 No. 2, pp. 250-279.

Hair, J., Black, W.C., Babin, B.J. and Anderson, R.E. (2010), Multivariate Data Analysis, 7th ed., Pearson Prentice Hall, Harlow.

Han, S.J., Bonn, M.A. and Cho, M. (2016), "The relationship between customer incivility, restaurant frontline service employee burnout and turnover intention", International Journal of Hospitality Management, Vol. 52, pp. 97-106.

Hobfoll, S.E., Halbesleben, J., Neveu, J.P. and Westman, M. (2018), "Conservation of resources in the organizational context: the reality of resources and their consequences", Annual Review of Organizational Psychology and Organizational Behavior, Vol. 5, pp. 103-128.

Hochschild, A.R. (1983), The Managed Heart: Commercialization of Human Feeling, University of California Press, Berkeley, CA.

Hur, W.-M., Rhee, S.-Y. and Ahn, K.-H. (2016), "Positive psychological capital and emotional labor in Korea: the job demands-resources approach", The International Journal of Human Resource Management, Vol. 27 No. 5, pp. 477-500.

Jensen, J.M., Patel, P.C. and Messersmith, J.G. (2013), "High-performance work systems and job control: consequences for anxiety, role overload, and turnover intentions", Journal of Management, Vol. 39, pp. 1699-1724.

Karadas, G. and Karatepe, O.M. (2019), "Unraveling the black box: the linkage between highperformance work systems and employee outcomes", Employee Relations, Vol. 41, pp. 67-83.

Karasek, R.A. (1979), "Job demands, job decision latitude, and mental strain: implications for job redesign", Administrative Science Quarterly, Vol. 24, pp. 285-308.

Karatepe, O.M. (2011), "Do job resources moderate the effect of emotional dissonance on burnout?", International Journal of Contemporary Hospitality Management, Vol. 23, pp. 44-65.

Karatepe, O.M. and Karadas, G. (2014), "The effect of psychological capital on conflicts in the workfamily interface, turnover and absence intentions", International Journal of Hospitality Management, Vol. 43, pp. 132-143.

Kilroy, S., Flood, P.C., Bosak, J. and Chênevert, D. (2016), "Perceptions of high-involvement work practices and burnout: the mediating role of job demands", Human Resource Management Journal, Vol. 26, pp. 408-424.

Kloutsiniotis, P.V. and Mihail, D.M. (2019), "Is it worth it? Linking perceived high-performance work systems and emotional exhaustion: the mediating role of job demands and job resources", European Management Journal, No. 4, doi: 10.1016/j.emj.2019.12.012.

Kooij, D.T., Jansen, P.G., Dikkers, J.S. and De Lange, A.H. (2010), "The influence of age on the associations between HR practices and both affective commitment and job satisfaction: a metaanalysis", Journal of Organizational Behavior, Vol. 31, pp. 1111-1136.

Kroon, B., Voorde, K.V.D. and Veldhoven, M.V. (2009), "Cross-level effects of high-performance work practices on burnout: two counteracting mediating mechanisms compared”, Personnel Review, Vol. 38, pp. 509-525. 
ER

43,6

Lee, L. and Madera, J. (2019), "A systematic literature review of emotional labor research from the hospitality and tourism literature", International Journal of Contemporary Hospitality Management, Vol. 31, pp. 2808-2826.

Lepak, D.P., Liao, H., Chung, Y. and Harden, E.E. (2006), “A conceptual review of human resource management systems in strategic human resource management research", in Martocchio, J.J. (Ed.), Research in Personnel and Human Resources Management, JAI, Greenwich, Vol. 25, pp. 217-271.

Luthans, F. and Youssef-Morgan, C.M. (2017), "Psychological capital: an evidence-based positive approach”, Annual Review of Organizational Psychology and Organizational Behavior, Vol. 4, pp. 339-366.

Luthans, F., Avolio, B.J., Avey, J.B. and Norman, S.M. (2007), "Positive psychological capital: measurement and relationship with performance and satisfaction", Personnel Psychology, Vol. 60, pp. 541-572.

Madera, J.M., Dawson, M., Guchait, P. and Belarmino, A.M. (2017), "Strategic human resources management research in hospitality and tourism", International Journal of Contemporary Hospitality Management, Vol. 29, pp. 48-67.

Mansour, S. and Tremblay, D.G. (2018), "Work-family conflict/family-work conflict, job stress, burnout and intention to leave in the hotel industry in Quebec (Canada): moderating role of need for family friendly practices as "resource passageways"”, The International Journal of Human Resource Management, Vol. 29 No. 16, pp. 2399-2430.

Min, H., Kim, H.J. and Lee, S.B. (2015), "Extending the challenge-hindrance stressor framework: the role of psychological capital", International Journal of Hospitality Management, Vol. 50, pp. 105-114.

Newman, A., Ucbasaran, D., Zhu, F.E.I. and Hirst, G. (2014), "Psychological capital: a review and synthesis”, Journal of Organizational Behavior, Vol. 35, pp. S120-S138.

Page, S., Bentley, T., Teo, S.T.T. and Ladkin, A. (2018), "High performance work systems and workplace bullying in visitor economy", International Journal of Hospitality Management, Vol. 74, pp. 122-129.

Peccei, R. and Van De Voorde, K. (2019), "Human resource management-well-being-performance research revisited: past, present, and future", Human Resource Management Journal, No. 4, doi: 1111/1748-8583.12254.

Podsakoff, P.M., MacKenzie, S.B. and Podsakoff, N.P. (2012), "Sources of method bias in social science research and recommendations on how to control it", Annual Review of Psychology, Vol. 63, pp. 539-569.

Qiu, H., Li, M., Shu, B. and Bai, B. (2020), "Enhancing hospitality experience with service robots: the mediating role of rapport building", Journal of Hospitality Marketing and Management, Vol. 29 No. 3, pp. 247-268.

Salazar, M. (2018), "How high employee turnover is affecting the restaurant industry", Michelin Magazine, available at: https://guide.michelin.com/us/en/california/article/features/restaurantemployee-turnover (assessed 30 December 2019).

Schaufeli, W.B. and Bakker, A.B. (2004), "Job demands, job resources, and their relationship with burnout and engagement: a multi-sample study", Journal of Organizational Behavior, Vol. 25, pp. 293-315.

Smith, R. (2018), "Stress in the restaurant industry", Restaurant \& Catering Magazine, 18/06/2018, available at: http://rca.asn.au/magazine/stress-in-the-restaurant-industry/ (accessed 31 December 2019).

Sun, L.Y. and Pan, W. (2008), "HR practices perceptions, emotional exhaustion, and work outcomes: a conservation-of-resources theory in the Chinese context", Human Resource Development Quarterly, Vol. 19, pp. 55-74. 
Teo, S.T.T., Bentley, T. and Nguyen, D. (2019), "Psychosocial work environment, work engagement, and employee commitment: a moderated, mediation model", International Journal of Hospitality Management. doi: 10.1016/j.jijm.2019.102415.

Townsend, K., Wilkinson, A., Allan, C. and Bamber, G. (2012), "Mixed signals in HRM: the HRM role of hospital line managers", Human Resource Management Journal, Vol. 22, pp. 267-282.

HCHRM and burnout of food service employees

Van De Voorde, K. and Beijer, S. (2015), "The role of employee HR attributions in the relationship between high-performance work systems and employee outcomes", Human Resource Management Journal, Vol. 25, pp. 62-78.

Van De Voorde, K., Veld, M. and Van Veldhoven, M. (2016), "Connecting empowerment-focused HRM and labour productivity to work engagement: the mediating role of job demands and resources", Human Resource Management Journal, Vol. 26 No. 2, pp. 192-210.

van Veldhoven, M., Van den Broeck, A., Daniels, K., Bakker, A., Tavares, S. and Ogbonnaya, C. (2020), "Challenging the universality of job resources: why, when, and for whom are they beneficial?", Applied Psychology, Vol. 69, pp. 5-29.

Volmer, J., Spurk, D. and Niessen, C. (2012), "Leader-member exchange (LMX), job autonomy, and creative work involvement", The Leadership Quarterly, Vol. 23 No. 3, pp. 456-465.

Wang, Y.C., Luo, C.C. and Tai, Y.F. (2017), "Implementation of delightful services: from the perspective of frontline service employees", Journal of Hospitality and Tourism Management, Vol. 31, pp. 90-104.

Whitener, E.M. (2001), "Do 'high commitment' human resource practices affect employee commitment? A cross-level analysis using hierarchical linear modeling", Journal of Management, Vol. 27, pp. 515-535.

Wong, S.S., DeSanctis, G. and Staudenmayer, N. (2007), "The relationship between task interdependency and role stress: a revisit of the job demands-control model", Journal of Management Studies, Vol. 44, pp. 284-303.

Xanthopoulou, D., Bakker, A.B., Demerouti, E. and Schaufeli, W.B. (2007), "The role of personal resources in the job demands-resources model”, International Journal of Stress Management, Vol. 14, pp. 121-141.

Yin, H., Wang, W., Huang, S. and Li, H. (2018), "Psychological capital, emotional labor and exhaustion: examining mediating and moderating models", Current Psychology, Vol. 37, pp. 343-356.

Zhang, X., Lin, Z., Liu, Y., Chen, X. and Liu, D.M. (2020), "How do human resource management practices affect employee well-being? A mediated moderation model”, Employee Relations, Vol. 42 No. 4, pp. 903-919.

Zhong, L., Wayne, S.J. and Liden, R.C. (2016), "Job engagement, perceived organizational support, high-performance human resource practices, and cultural value orientations: a cross-level investigation", Journal of Organizational Behavior, Vol. 37, pp. 823-844. 
ER

43,6

1360

Appendix

\begin{tabular}{|c|c|c|c|}
\hline Constructs and items & Mean & SD & $\begin{array}{l}\text { Standardized } \\
\text { loading }\end{array}$ \\
\hline
\end{tabular}

HCHRM practices

Salary

I am not getting underpaid in comparison with colleagues doing similar work within my company

Regarding the work I do, I am not getting underpaid

As far as I know, salary within my company is equal to, or even better than in, comparable companies

$\begin{array}{llll}4.44 & 1.74 & 0.71 & 18.11 \\ & & & \\ 4.12 & 1.71 & 0.86 & 40.56 \\ 4.25 & 1.57 & 0.91 & 70.23 \\ & & & \\ & & & 75.32 \\ 4.32 & 1.46 & 0.91 & 60.68 \\ & & & 64.04\end{array}$

Procedural justice

Management rules on disputes only after it investigates all sides of the issue thoroughly

Workers have a chance to answer any complaints made against them

Our company has formal procedures to ensure that workers are treated fairly

Job security

Workers can get a certain amount of pay every pay period without delay Workers can be expected to stay in the organization for as long as they wish

4.86

\section{Training}

Extensive training programs are provided for workers in my company

Formal training programs are offered to workers in order to increase their promotability

\section{Job autonomy}

Do you have a choice in deciding HOW you do your work?

Do you have a choice in deciding WHAT you do at work?

Job demands

Do you have to work very fast?

Do you have to work very intensively?

Does your work demand too much effort?

\section{Psychological capital}

\section{Self-efficacy}

I feel confident contributing to discussions about the company's strategy I feel confident presenting information to a group of colleagues

Resilience

I can be "on my own", so to speak, at work if I have to

I usually take stressful things at work in my stride

before

Hope

I can think of many ways to reach my current work goals

At this time, I am meeting the work goals that I have set for myself

\section{Optimism}

I always look on the bright side of things regarding my job work

Burnout

It happens more and more often that I talk about my work in a negative way

After work, I tend to need more time than in the past in order to relax and

3.25

Table A1.

During my work, I often feel emotionally drained

Over time, one can become disconnected from this type of work

After my work, I usually feel worn out and weary 
About the authors

Stephen T.T. Teo is Professor of Work and Performance and Professorial Research Fellow at Edith Cowan University, Australia. Prior to this appointment, he was the Interim Director of the Global Business Innovation Research Platform at RMIT University. He has published in leading refereed journals such as Human Resource Management (USA), Human Resource Management Journal, Journal of Vocational Behaviour, the International Journal of Human Resource Management, International Business Review, Asia Pacific Journal of Management, and others such as the Journal of Advanced Nursing. His most recent projects examined the impact of organisational change on the well-being and performance of public sector employees in Australia, New Zealand, the United Kingdom, the USA and Italy. He is currently undertaking research into workplace ill-treatment and psychological capital. Stephen T.T. Teo is the corresponding author and can be contacted at: drstephen.teo@gmail.com

Diep Nguyen is the HDR Coordinator and a Lecturer at the School of Business and Law, Edith Cowan University, Australia. Prior to this appointment, she was a Post-Doctoral Research Fellow. Her research has appeared in International Journal of Hospitality Management, Asia Pacific Journal of Management, Public Management Review, Australian Journal of Public Administration, Personnel Review, Journal of General Management and New Zealand Journal of Employment Relations. She is currently researching Strategic HRM, workplace behaviors including workplace bullying, incivility and employee wellbeing in public sectors in Vietnam.

Azadeh Shafaei has previously worked as a Postdoctoral Research Fellow at the School of Business and Law and a Senior Lecturer at Graduate Research School, Edith Cowan University. She has also worked as a Research Assistant at the School of Business and Law, ECU on different occasions. Prior to joining Edith Cowan University, Dr. Azadeh Shafaei was a Senior Researcher at Australian Council for Educational Research (ACER).

Tim Bentley is Professor of Work and Wellbeing and acting Associate Dean Research in the School of Business and Law, and he works with the School's Centre for Work and Organisational Performance (CWOP). His research focuses on psychosocial risks, occupational health, safety and wellbeing, and human factors issues in work. Tim's most recent research activity focuses around an initiative he leads, the New Zealand Workplace Barometer, that monitors the presence and impact of psychosocial risks within a large number of New Zealand workplaces. Tim also leads an HRC/WorkSafe NZ funded study evaluating the effectiveness of psychosocial safety climate as an organizational intervention to reduce psychological health outcomes associated with psychosocial risks.
HCHRM and burnout of food service employees

1361

For instructions on how to order reprints of this article, please visit our website:

www.emeraldgrouppublishing.com/licensing/reprints.htm

Or contact us for further details: permissions@emeraldinsight.com 